\title{
The study of extracurricular reading in history teaching
}

\author{
Guojun Sun ${ }^{1, a}$ \\ ${ }^{1}$ The Journal of Chifeng University,024000,China \\ aemail: comcfsgj@163.com
}

Keywords: School, History teaching, Extracurricular reading, Study

\begin{abstract}
Reading is one of the most important ways of human learning, While the reading teaching is one of the most effective teaching methods. In the history teaching actively carries out extra-curricular reading, it is conducive to the consolidation and deepening of teaching content, it is conducive to the development and extension of the history of the problem, which is conducive to the students' learning interest in the excitation and comprehensive ability of the training. Outside reading is a process of nourishing the heart and opening the wisdom, which can inspire people to think about the world and their own, to promote young people to gradually recognize themselves and actively think about their future.

In the teaching of history, we should actively guide students to read, in particular, extra-curricular reading, will learn to read and after class reading together. The history teachers should set up the concept of "history", and encourage students to read more extracurricular books, try to expand their knowledge, stimulate students' interest, and improve their personality.
\end{abstract}

\section{Actively carrying out extra-curricular reading, and expanding the knowledge, cultivate interest in reading is the most lasting, the most common way to obtain information.}

If a person who wants to learn to learn, first of all he has to learn to read. Reading comprehension ability is the most important and basic ability of all kinds of learning ability. Therefore, in the teaching of history, we should pay special attention to the cultivation of students' reading ability. As the saying goes, "interest is the best teacher". In history teaching, the teachers should thoroughly understand the textbook and grasp the material essence, to explore the teaching contents and real contact, identify can stimulate students' interest and knowledge of topic inducts the new class; to fully mobilize students' history learning and reading the enthusiasm and initiative, let the students curiosity, doubt and suspense or moved into the history and historical figures and historical events "with destiny, a total of breathing, after-school still" divertissement not "' stop ", and actively carry out extra-curricular reading, to explore the historical figures and historical events, thus completing the" want me to learn "to" I want to learn ". In the current historical materials, the majority of the imported or a large number of historical figures, historical events and other pictures, teachers can use these to guide students to read, but also according to the theme of the text to guide students to read, so that students in the course of reading knowledge, enrich teaching content, deepen the understanding of teaching materials, and enhance the historical and emotional, to cultivate interest in learning.

To achieve this aims, the teachers should carefully select some extracurricular books to recommend the students to promote their further reading, so as to deepen the understanding of classroom teaching content, enhance the effect of historical education, and promote the sustainable development of students learning ability, and ultimately to achieve the teaching goal of "teach people to fish".

Here are some recommendations for reference: (1) A good version of the famous works of famous writers; (2) To recommend a good book of authority; (3) To recommend a combination of popular and professional books; (4) To have an association with teaching materials and should be less and less refined; (5) Recommend the books which should be read by the teacher himself or the more familiar and familiar. 


\section{Make good use of information technology to carry out the history of extra-curricular reading activities}

The resources are very rich in history teaching. In addition to the teaching materials, teaching equipment, historic site, external, and internet is very convenient effective resources. The use and development of history teaching resources are related to teaching level, teaching quality and teaching effect. Scientific use and development of history teaching resources are conducive to stimulate students' interest, helping to improve the teaching effect, and it is conducive to the effective realization of the goal of history curriculum. The introduction of modern information technology in the history of innovation, the history of extra-curricular teaching, is conducive to the development of the history of classroom teaching, so as to cultivate students' ability to gather information and explore the problem. On the one hand, the teachers can make full use of modern information technology and network technology, network of history data, picture search, also can use the online resource rich courseware, display and reproduction of history, historical figures and historical events to sings with fresh form presented in front of students, make students feel real and vivid feeling and true to life. On the other hand, it is more important for students to learn to use the internet to read, search and find information and information. In fact, the use of modern information technology is a new type of teaching method of innovation history, which combines the advantages of traditional teaching and network teaching, and can better play its due advantages, functions and effects. For example, online reading. According to the specific content of history teaching (characters, events, etc.), in the Internet to find relevant historical information, pictures, online reading history. At the same time, it can also be immediately retrieved to the relevant information on the big screen, and then read and start the corresponding historical teaching activities. This use of modern information technology innovation in the history of extra-curricular teaching practice, breaking the traditional teaching method, so that students participate in teaching activities, to expand the variety of channels to obtain information, broaden the knowledge sources, stimulate students' interest in learning history, to cultivate students' ability to collect, collate, deal with the ability of students to develop and improve.

\section{The function and significance of the history after class reading}

The history outside reading can help to stimulate students' Patriotism. The moral education in the history teaching, especially the patriotism education has very important significance. Over the past few years the history of extra-curricular reading, it helps to greatly stimulate students' patriotism. Through the study of the modern history of China, many students said that the Chinese nation has a long history, splendid ancient civilization, we are descendants of the dragon and proud. We must strive to learn and develop our country's outstanding cultural heritage, inherit the fine tradition of the Chinese nation, let Oriental huge dragon to restore its former glory. Some students still in the diary, a spirit calling: don't forget national humiliation, alarm should always sounded, I love China, it is the strongest voice in our hearts. Through educational activities, the students deeply realize that there is no new China without the Communist Party, and only socialism can save China, and only socialism can develop China, which is the price of blood and tears after the Chinese people come to the truth. From the modern Chinese national humiliation and fight, to let the students understand the lessons to take a beating behind.

History after class reading is helpful to the formation of students' good character. One important goal of history teaching is to cultivate students' good character, the truth, the beauty of the soul, and let the students seek the truth, know the truth, respect and defend the truth. In the Chinese nation's long history, there have been many epic, tear jerking of historical figures and historical events, emerged a large number of immortal examples and role models, these historical figures and events to affect a student's character, edifying their sentiments, contributed to the development of physical and mental health.

History after class reading is beneficial to students' learning interest and understanding of teaching materials. History itself is broad and rich. Learning history is of intense interest. However, due to the influence of the traditional teaching ideas, the history of vocational education is a serious 
program, so that the history of teaching has become dull and boring, students learning interest in a downward trend. Therefore, reform of history teaching in secondary vocational schools and the extracurricular reading should conform to the requirements of the new situation, fully consider students' feelings, the discipline of history becomes rich and colorful, with immense interest. Bruner has long been the focus of language to warn people: "the best stimulus, but the interest of the learning materials." The great function of interest can become the inexhaustible motive force for the students to study. Therefore, the history teaching in the secondary vocational school should focus on the study of stimulating students' learning interest. Practice has proved that in the history teaching of secondary vocational school, through extra-curricular reading, not only deepened the understanding of the contents of the teaching material, but also expanded the knowledge of students, broaden the horizons, mobilize the enthusiasm and initiative of learning history, to cultivate the interest of learning history.

\section{History after class reading can make the students get into history, it is conducive to active classroom atmosphere.}

In the history teaching, the materials can let the students choose the content related to the content of the textbook, read the extracurricular books, find the material, after careful preparation to the classroom to carry on the lecture. For example, in talking about the Second World War the German Fascist persecution of the Jews, let the students to see the Jewish history of tears of blood "and other books, his analysis and German fascists mad persecution of the Jews and the typical case and in the classroom to fascist atrocities complaint. In this way, the history of extra-curricular reading can mobilize the enthusiasm and initiative of the students to learn, to stimulate their reading desire, so that they read and some useful things from.

We should let the students participate in teaching, so that students from passive learning to active learning, from the beginning of the organization of classroom discussion. We organize the discussion "in the 1929-1 933 years of economic crisis hit, the United States why not as Germany, Japan as the fascist dictatorship of the country?" And other issues. After exploration and practice, we further ask students to choose the contents of the textbooks and the subject, to see their own textbooks, reading books, looking for materials, and then to the classroom lecture. For example, talked about the German Fascist persecution of the Jews, let the students speaking the Jewish history of tears of blood ", analysis of fascist Germany mad persecution of Jews, accused of fascist atrocities; speak" Mountbatten program "and the partition of India students up tell the origin and present situation of Kashmir to supplement the lack of textbooks; and students about the end of the cold war, world politics, economic development trends and so on. The students' problems are related to the contents of the text, but it is beyond the scope of the course, which is undoubtedly good for improving students' learning ability. The students agreed that such a lesson is very new and learned a lot of knowledge from books. For example, students about "the Asian African Conference of Zhou Enlai", so that we deeply feel to Zhou Enlai the great proletarian revolutionaries who have courage, broad mind, ingenious art of struggle, and his image of tall handsome, charming charm and richness. Another example, after the students finished Mandela's legendary life, the teacher talked about his feelings. He said, I am also worried that Mandela will be the president of the white man after revenge, but he did not do so, why? The students told the question. Mandela said: "in prison, I have reduced the hatred of the white, but the system of hatred has increased." He hated the South African apartheid system, which he thanked for the white man's contribution to the development of the country. This is how broad the mind! Fundamentally speaking, the history of how to be a man, only to let the students fully participate in teaching, to make it deeply feel the history of education, the above example is proved. , "I read I am happy" what are the experience.

\section{References}

[1] C. Wang. History teaching should pay attention to the extracurricular reading instruction. Anhui education,1990, (11). 
[2] Quarterly dividend. Guide students to read the history of the history book. history teaching, 2004, (01).

[3] G.D. Du. High school history and extracurricular reading. the road to success, 2012, (14).

[4] F.X. Wang. The history of senior high school under the new curriculum standard should strengthen the students' extracurricular reading.New courses, 2011, (05). 